\title{
ALK Gene Rearrangement Negative
}

National Cancer Institute

\section{Source}

National Cancer Institute. ALK Gene Rearrangement Negative. NCI Thesaurus. Code

C134487.

A genetic finding indicating that rearrangement of the ALK gene has not been detected in a sample. 